
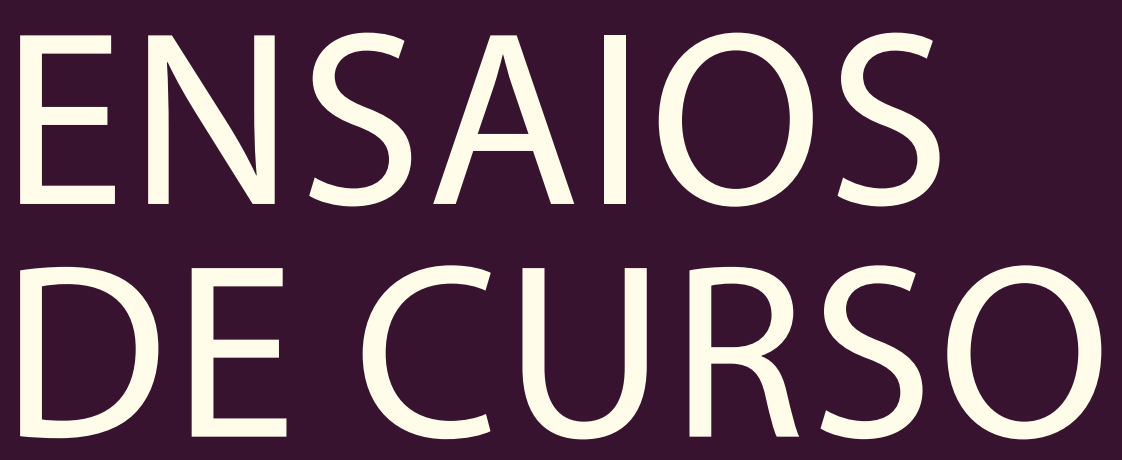



\section{MICHEL BUTOR, VOZ(ES)}

- AMAYI LUIZA SOARES KOYANO

\section{RESUMO}

O escritor francês Michel Butor (1926-2016) refletiu sobre a voz e os efeitos da vocalidade e da oralidade na tradução, enquanto criação literária, e na leitura enquanto performance. Para este presente ensaio, proponho um percurso de análise que se inicia com o livro sonoro Pensées à voix haute (BUTOR, 2017) e de sua relação com as teorias sobre a voz (ZUMTHOR, 2018; DoLAR, 2014; Cesarino, 2014; Cavarero, 2011; Meschonnic, 2006), passando pela técnica de registro sonoro e de tradução do escritor para a elaboração do poema "Manhattan invention" (ButoR, 2008 [1962]; 2004), culminando na análise de seu livro para crianças Zoo (BUTOR, 2001) do ponto de vista da formação do leitor na infância e da performance da leitura em voz alta. Butor, analisado segundo os teóricos da voz, imprime na tradução e na leitura o que há de mais contemporâneo dentro dos estudos discursivos: a abertura às múltiplas vozes a partir da unicidade vocálica.

Palavras-chave: Michel Butor; Voz; Tradução; Leitura.

\section{ABSTRACT}

The French writer Michel Butor (1926-2016) reflected upon voice and vocality and the effects of orality on translations, such as in literary creations, and in reading as a performance. For this present essay, I propose a course of analysis that begins with the audiobook Pensées à voix haute (BUTOR, 2017), and its relationship with theories on the voice (ZUMTHOR, 2018; DOLAR, 2014; CESARINO, 2014; CAVARERO, 2011; MESCHONNIC, 2006), following the writer's technique on voice recording and translation for the elaboration of the poem "Manhattan invention" (BUTOR, 2008 [1962]; 2004), culminating in the analysis of his children's book Zoo (BUTOR, 2001), from the point of view of the development of the reader during childhood and the performance of reading aloud. Butor, analyzed by theorists of the voice, imprints in translation and reading what is most contemporary within the discursive studies: the opening to the multiple voices from vocal unity.

Keywords: Michel Butor; Voice; Translation; Reading. 
IO que há de oral e de vocalizado nas obras de Michel Butor?", o leitor pode se questionar. Butor, romancista, ensaísta, poeta e artista plástico, explorou a questão da voz autoral de múltiplas formas em diversos meios, como em livros de artista, literatura infantil, em parcerias com outros artistas músicos, pintores - e em livros sonoros, como Pensées à voix haute, publicado em 2017 e organizado por capítulos não hierarquizados, mas alfabéticos, em que cada letra representa uma porta de entrada para a obra. Mas o que o escritor disse especificamente sobre a voz? Como ele a concebia em seus trabalhos?

O objetivo central que orienta este ensaio é exatamente o de apresentar e discutir os aspectos da voz segundo Michel Butor e a partir, também, de textos teóricos sobre a voz (Zumthor, 2018; Dolar, 2014; Cesarino, 2014; Cavarero, 2011; Meschonnic, 2006). Além da discussão e da análise do que chamo de livro sonoro, o Pensées à voix haute, proponho avançar e dialogar com outros dois textos: o poema "Manhattan invention", originalmente publicado em Mobile (BUTOR, 2008 [1962]) e pertencente também à obra Anthologie nomade (BUTOR, 2004), e o livro de literatura infantil Zoo (Butor, 2001). A fim de melhor discutir os aspectos principais sobre a presença da voz na obra butoriana e de melhor analisar os textos selecionados, a divisão deste ensaio será composta das partes "Tradução" e "Leitura", cada uma sendo acompanhada da análise de um dos textos, respectivamente.

Antes de aprofundar as questões no que tange à voz levantada na obra, faz-se necessário uma breve reflexão sobre o título Pensées à voix haute. Ao contrário do que postula Cavarero (2011, p. 60), segundo o qual "[...] o problema pode ser formulado como uma subordinação do falar ao pensar em que o último projeta sobre o primeiro a sua marca visual", vemos neste livro sonoro de Butor, concebido na forma de áudio e registrado em $C D$, exatamente o contrário: o escritor subordina o pensar à vocalização; sem voz, o pensamento não se completa e, portanto, não está apto a transformar as formas tradicionais de se fazer um livro. "A afinidade entre pensamento e palavra, ou melhor, o fato de que o primeiro deriva da segunda, situa a mente e as atividades intelectuais no aparato respiratório e nos órgãos de fonação. É [...] a phoné que determina a fisiologia do pensamento" (idem, p. 84).

Além do que concerne aos temas de tradução e de leitura, Butor apresenta nessa obra oral ainda duas outras importantes características da voz que merecem ser aqui citadas: o riso e a surdez. Para ele, o riso desempenha um importante papel em sua vida:

J'aime rire et j'ai un rire assez sonore, je ris bruyamment. C'est pour moi une espèce de libération de rire, donc j'aime beaucoup provoquer le rire chez moi, j'aime beaucoup avoir des 
occasions de rire. En ce qui concerne mon œuvre, la question est de savoir est-ce qu'il y a du comique à l'intérieur de ce que j'ai écris, et bien je l'espère de tout mon cœur. J'ai essayé de rivaliser dans certains textes avec des écrivains que j'admire justement à cause de leur caractère comique, à cause de la façon dont ils provoquent un rire qui peut être un rire bruyant comme le mien ou bien qui peut être un rire très délicat et naturellement je cherche la délicatesse dans le rire. Quand je suis en bonne société, je me force de contrôler un peu mon rire mais je ne peux pas du tout y renoncer, j'ai absolument besoin de rire. (Butor, 2017, [s.p.], destaques meus)

[1] Pesquisa sobre o riso das hienas realizada pela ASA. Disponível em: https://exploresound. org/2017/01/just-giggling-information-content-of-the-hyenas-laugh/.
A expressividade do riso, em especial do riso barulhento que Butor diz possuir, manifesta aspectos da unicidade da voz (cf. CAVARERo, 2011). Riso é voz? Talvez seja um reflexo da voz, da ordem do suspiro, do grito, visto que é impossível renunciar à própria risada e à própria maneira de rir. Rir-se do jeito que se ri, portanto, de um jeito único. É possível controlá-lo, até certo ponto, como também é possível controlar e modular a própria voz, mas ele reflete também a unicidade de quem ri. "Je me force de contrôler un peu mon rire mais je ne peux pas du tout y renoncer", declara o escritor (BuTOR, 2017, [s.p.]). O riso é irrenunciável, assim como a própria voz. "A impalpabilidade das vibrações sonoras", esclarece Cavarero, "mesmo incolores como o ar, sai de uma boca úmida e irrompe do vermelho da carne", e é também por seu caráter de origem corporal que "a voz é o equivalente daquilo que a pessoa única possui de mais escondido [...] de uma vitalidade profunda do ser único que goza da sua autorrevelação por meio da emissão da voz" (2011, p. 18-19). A emissão da voz permite o gozo da autorrevelação por parte do sujeito emitente, mas ela é "pura alteridade, ela previne a autorreflexão. Nesse papel, ela até mesmo assume uma função estrutural muito parecida com a do tempo" (DoLAR, 2014, p. 159); não se escuta a própria voz da mesma forma que o Outro escuta a nossa voz, o que pode ser estendido para a autopercepção do próprio riso. A voz, para Dolar, está entre o Sujeito e o Outro, não sendo posse de nenhum deles, do mesmo modo que não a possuem corpo e linguagem.

Assim como a voz, mais que revelar e prevenir a autorreflexão, o riso comunica, por meio de uma relação estabelecida com outra unicidade, a de quem a emite (CAvarero, 2011, p. 20). Não é preciso palavra para comunicar o riso, pois o "âmbito da voz", do qual o riso faz parte, "é constitutivamente mais amplo que o da palavra: ele o excede" (idem, p. 28). Se a voz é phoné semantiké, voz significante, o riso e todas as suas variantes também o seriam. Pode-se pensar que algumas espécies animais, como as hienas' ${ }^{1}$, também riem, sendo o riso, portanto, puramente phoné, da ordem do animalesco. Ora, o riso da hiena, ao 
que estudos da Acoustical Society of America (ASA) indicam, está relacionado ao modo de geolocalização noturna e à hierarquização de determinado grupo, não aos aspectos não discursivos das emoções, como no nosso caso. No Ocidente, o riso comunica uma infinidade de informações indo além do humor: alegria, descontração, mas também frustração, nervosismo, tensão e excitação. Ele não serve para nos organizarmos em castas, como no caso das hienas, mas para nos tornar capazes, assim como a voz, de nos relacionarmos com outras unicidades, com o Outro. Riso é alteridade manifesta do eu.

Butor tem razão em valorizá-lo e em buscar rir e fazer os outros rirem. O riso faz parte não só da vida ordinária, do dia a dia, como do trabalho do escritor que em sua literatura busca despertar a delicadeza do riso em seu leitor. Mas não só o riso é importante para o escritor: a surdez teve um impacto muito grande em sua vida.

La surdité a joué un grand rôle dans ma vie parce que ma mère est devenue sourde lors de la naissance de ma dernière sœur. Ça a été pour moi un drame. Elle est devenue sourde progressivement et puis après ce dernier accouchement elle est devenue complètement sourde. Ça a posé d'état de problème dans ma famille, naturellement. Beethoven c'était le musicien sourd, donc c'était celui pour qui la surdité était quelque chose de particulièrement dramatique. [...] Dans la figure de Beethoven pour moi il y avait une projection des problèmes de ma mère et puis ce paradoxe extraordinaire du musicien qui ne peut pas entendre ce qu'il fait. [...] mais la musique de Beethoven est extrêmement auditive [...] il y a une espèce de fureur à l'intérieur de sa musique qui vient en particulier de ce problème de la surdité. La musique est quelque chose qui est en train de lui échapper, il essaye évidemment de la rattraper par tous les moyens. (Butor, 2017, [s.p.])

Se"a voz, qualquer coisa que diga, comunica antes de tudo, e sempre, uma só coisa: a unicidade de quem a emite" (CAVARERO, 2011, p. 40), a surdez retirou da mãe de Butor a escuta de outras unicidades vocálicas e trouxe a impossibilidade de estabelecer comunicação com essas outras unicidades, incluindo a própria mãe, avó materna do escritor. A solidão que recaiu sobre ela tem sua fonte no isolamento acústico de sua nova condição de estar no mundo e não mais ser notada e reconhecida pela unicidade de sua voz. O cerco que se instalou ao seu redor, composto do marido e dos sete filhos, de falantes que não mais emitem a própria voz mas apenas manifestam nos lábios a forma das palavras, possibilitou que a comunicação se estabelecesse entre eles, mas não amenizou 
o isolamento acústico por ela sofrido. A referência a Beethoven deixa claro que o escritor via no músico uma projeção dos problemas auditivos da mãe. Beethoven não escutava a música por ele produzida: podia sentir as vibrações sonoras por ele criadas durante a execução de sua música, tentativa de escuta diferente daqueles sem problemas auditivos. Assim como o músico, podemos pensar que a surdez da mãe do escritor não retirou dela a unicidade de sua voz, mas a impossibilitou de estabelecer o vínculo entre si, enquanto Sujeito, e o Outro.

Butor percebia em Beethoven um furor em sua música cuja origem residia na própria surdez do músico, que, de diversos modos, tentava que não lhe escapasse. De algum modo, essa projeção que o escritor estabeleceu entre a mãe e o músico, surdos, o fez perceber que o problema da mãe poderia, como no caso de Beethoven, gerar uma nova forma de comunicação com o mundo que representasse um atalho em relação à unicidade expressa pela voz. A mãe de Butor não perdeu por completo sua comunicação com o mundo; ela ficou apenas confinada à segurança dos que ela podia "ouvir" e que a "escutavam" em sua surdez. Sua voz, única, e toda a metáfora presente na relação de pensamento e voz (cf. DolAR, 2014) não podiam ser apagadas pela surdez causada pela última gravidez. Assim como dos mortos nossa mente, até certo ponto, registra as vozes, a surdez também não é capaz de apagar o registro vocálico que passa a fazer parte de nós, mesmo na ausência do corpo e da escuta do Outro. A voz também se aloja na memória; entretanto, por não pertencer nem ao Sujeito nem ao Outro, não é posse da memória, mente, corpo e linguagem (cf. DolAR, 2014).

\section{TRADUÇÃO}

Michel Butor aborda a tradução em dois momentos durante a obra Pensées à voix haute: em "Autres autres", que pertence ao capítulo "Autre", e em "Représentations collectives", do capítulo "Engagements". A tradução, para Butor, adquire um caráter de unicidade vocálica (CAVARERO, 2011, p. 16) capaz de transmitir múltiplos sentidos para um mesmo texto: a depender das intenções do tradutor e de suas habilidades tradutórias. O emprego da tradução na escritura butoriana deve-se ao seu desejo "de faire parler les autres" (BuToR, 2017, [s.p.]), de registrar suas vozes, tal como ocorre com o registro fonográfico, e de transformá-las em personagens que, em certa medida, se assemelham ao próprio escritor que as escuta e as apreende por meio de seus discursos. A prática tradutória, para Meschonnic (2006, p. 8), vem reconhecendo a oralidade e se transformando a partir dessa percepção, que é componente da renovação na teoria da linguagem, sendo esta indissociável da teoria da literatura. Butor, analisado segundo Meschonnic, imprime na tradução o que há de mais contemporâneo dentro dos estudos discursivos: 
J'ai commencé par écrire des romans et là-dedans j'ai essayé de faire parler des personnages, des personnages qui me ressemblait à certains égards et qui pourtant était autre par certains signes essentiels [...] donc il avait des signes qui me distinguaient dans tels personnages. Et puis après ça, quand je voyageais de plus en plus, je me suis efforcé de faire parler les gens quej'avais rencontré, par exemple, lorsquej'ai voulu parler des Etats-Unis, le seule moyen pour moi ça a été de trouver du discours américain, du langage américain à faire passer en français. [...] J'ai donc essayé de faire parler les américains eux-mêmes, j'ai tendu une espèce de micro, si vous voulez, à la population américaine et pour d'autres pays du monde ça a été pareil, je n'ai pas pu me passer de l'intermédiaire de la littérature au-delà des ces pays-là. (BuToR, 2017, [s.p.])

Butor, enquanto intermediário da literatura, dá voz às pessoas que conheceu em suas viagens ao exterior. As viagens permeiam suas obras tanto quanto os discursos que elas representam. Partindo do desejo de retratar os países que visitou, o escritor registrou os discursos de seus povos, com "une espèce de micro" (idem, [s.p.]) que capta as vozes tal como elas são, garantindo assim a fidedignidade pretendida pelo escritor em suas representações vocálicas. Vemos, nesse ponto, que a voz para Butor permeia a tradução que ele realiza desses discursos: ele não teoriza diretamente a voz, mas exprime a importância que ela possui nos discursos que capta e que o cercam. $O$ uso de uma espécie de microfone, como ele relata, ressalta a importância da oralidade e da vocalidade na criação das imagens pretendidas, visto que "o âmbito da voz é constitutivamente mais amplo que o da palavra: ele o excede". Não se trata, portanto, de um registro que apenas "liga a voz à palavra" (CAVARero, 2011 , p. 28), mas que busca unir "o funcionamento da voz enquanto portadora de linguagem", portanto oralidade, ao "conjunto das atividades e dos valores que Ihe são próprios, independente da linguagem" (idem, p. 27), portanto vocalidade. Isso porque a oralidade passa pela unicidade do sujeito portador da voz, enquanto a vocalidade abarca todos os valores empregados pelo autor na prática de empregar a voz enquanto ferramenta literária de grande valor estético por seu caráter fônico.

Butor dá voz aos personagens que narra, os fazendo falar em um cruzamento entre a cultura proveniente desses discursos e a sua, francesa. Sua percepção do outro e dos outros - "des personnages plus au moins individuels puis des discours qui sont collectifs [...] des discours qui ne sont pas considérés comme les expressions d'individu mais comme l'expression de la foule ou de la majorité [...]" (ButoR, 2017, [s.p.] ) -, no entanto, não deixa de atravessar o 
seu logos francês, objetivo final de sua escritura - "[...] il fallait que je trouve une façon de dire en français ces choses-là avec toutes les disons, toute la profondeur qui peut y avoir à l'intérieur d'une traduction [...]" (idem, [s.p.]). 0 dizer que Butor suscita aos outros não franceses remete ao "quem fala?", que, "enquanto único e, sobretudo, enquanto aberto à unicidade de um outro", busca na compreensão do Dizer, "evento pelo qual os seres humanos, cada um e um ao outro, se falam, não importando o que dizem", o Dito, "que é, ao mesmo tempo, aquilo que eles se dizem e o que diz o inteiro saber do Ocidente, mas é, sobretudo, o sistema que organiza a palavra" (CAVARERo, 2011, p. 45-46).

O Dizer e o Dito, captados pelo microfone butoriano da escuta atenta, que pode ser entendido como uma metáfora ao ouvido, sofrem os efeitos do logos francês do escritor ao passar pela sua própria tradução desses registros fônicos. Butor, apesar da sua escuta ativa do discurso e dos modos de dizer dos Outros, faz parte da literatura dita francesa; ele não se pretende um escritor universal, sem logos definido ou mesmo de logos amplo e sem fronteiras. A França e os leitores franceses e francófonos são seu destino e objetivo, se não finais, maiores. A criação de sua escrita-mundo (cf. MoReLLo, 2012) passa pela França e pela sua língua materna e compõe a literatura de seu país.

Em relação aos efeitos causados pela tradução de textos ligados diretamente a uma cultura específica, Cesarino destaca a importância de questionar "até que ponto o trabalho de tradução altera ou não o 'mito',' se tomarmos a cultura ocidental e as múltiplas representações de seus povos, em especial a estadunidense para o caso de Mobile (BuToR, 2008 [1962]), como mítica, visto que, se "[...] o mito é justamente aquilo que melhor sobrevive às traições da tradução, não deixa também de ser verdadeiro que novos mitos se produzem (de maneira mais ou menos deliberada) justamente a partir das torções tradutórias" (CESARINO, 2014, p. 90). Nesse sentido, vale o questionamento: até que ponto ou medida as traduções butorianas geram torções tradutórias e, portanto, novos mitos dos povos retratados? O mito estadunidense apresentado por Butor em Mobile não deixa de sofrer interferências do escritor que o traduziu ao transformá-lo em literatura francesa. Esse é o ponto, pois não se trata nessa obra de produzir literatura estadunidense do ponto de vista de um francês, mas de remeter esses discursos gravados, essas outras vozes, a uma literatura com características bem distintas da norte-americana.

Em "Autres autres", o autor esclarece que, através da tradução, há uma voz que fala:

[...] dans une traduction on peut parler, on peut traduire toute sorte de chose différente dans un texte, on peut traduire la superficie du texte ou bien des choses beaucoup plus profondes, on peut traduire d'une façon tout à fait sérieuse et respectueuse 
ou bien il peut y avoir toute sorte d'ironie à l'intérieur même de la traduction. (BuToR, 2017, [s.p.])

A própria voz de quem traduz é impressa no texto traduzido. O tradutor é capaz de marcar uma tradução com ironia ou com seriedade e respeito, e ele pode ainda imprimir no texto traduzido a profundidade ou a superficialidade que lhe convier no ato de traduzir. Para Butor, é exatamente por esse caráter único do texto traduzido, em que a voz do tradutor ressoa através de suas escolhas lexicais, sintáticas e semânticas, que a descrição, as imagens que ele captou em suas viagens ao exterior e as vozes que registrou em seu "microfone", em especial nos Estados Unidos presente em Mobile, só podiam ser feitas por intermédio de sua própria tradução:

il a fallu naturellement que je les traduisent entièrement et il était essentiel que la traduction soit la mienne. Il était impossible pour moi d'utiliser des traductions déjà faites, d'abord pour la plupart de ces textes il n'y en avait pas, pour certains textes classiques il pouvait y en avoir mais qui ne me satisfaisait pas. (Butor, 2017, [s.p.])

Fica mais evidente ainda a voz do tradutor Butor, que é antes de tudo leitor e ouvinte desses discursos da alteridade, quando o escritor afirma que seu objetivo é de "faire passer des données essentielles de telle ou telle culture à l'intérieur de la mienne par une certaine lecture" (BuToR, 2017, [s.p.]). É por meio da leitura que se faz a tradução do Outro e de sua cultura, passando pelo filtro da cultura francesa do escritor e de suas características linguísticas. A tradução butoriana é do Outro, mas é também a sua própria enquanto personagem e enquanto escritor francês.

Et donc, l'écrivain furieux, si vous voulez, va dépenser une énergie extraordinaire pour réussir à vaincre cette impossibilité, pour réussir à dire ce que l'on n'était pas capable de dire auparavant. C'est ce qu'il fait d'ailleurs qui le si difficile pour l'écrivain de dire comment il procède de dire tout d'où il vient, puis qu'il s'agit de rendre dicible quelque chose qui auparavant ne l'était pas. C'est un manque, si vous voulez, c'est une obscurité, mas l'exemple des langues est très éclairant pour ça, on passe de l'une à l'autre, de quelque chose qu'on n'arrivait pas à dire en français, sauf avec des quantités des secondes locutions etc., et puis il y a un bon traducteur qui réussi a trouver ça, un bon traducteur qui se soit 
un traducteur directe ou indirecte, c'est-a-dire, qu'il traduisait effectivement une cuvre japonaise ou bien qu'il s'inspire de certains donnés de la culture japonaise pour faire quelque chose en français. Alors, là on voit très bien qu'on devient capable de dire quelque chose qui l'était très difficile de dire auparavant, et bien on peut généraliser ça, il s'agit de réussir à dire des choses qu'il était jusqu'à présent très difficiles de dire dans n'importe quelle langue. (idem, [s.p.])

A tradução se torna um meio, para o que Butor denomina "écrivain furieux" dizer o que era impossível de ser dito em uma língua, mas é possível se dizer em outra. É por intermédio da tradução direta ou indireta e do ponto de vista do escritor que a literatura francesa, e mesmo a literatura de qualquer outro país, alcança a possibilidade de se expressar de um modo antes inimaginável. "Relacionado à função do logos, como phoné semantiké, o problema da diversidade das línguas faz cair sobre a phoné uma sombra desfavorável" (CAvarero, 2011, p. 79), mas que, em Butor, é capaz de transformar os limites da língua francesa para além de suas possibilidades linguísticas. A phoné passa a exercer o ponto de partida do encontro entre as línguas e as possibilidades particulares que carregam, fazendo com que a tradução seja a ponte através da qual o "écrivain furieux" percorrerá o caminho do Dizer em uma língua o que só era possível de ser Dito em outra.

O poema "Manhattan invention" traz uma multiplicidade de vozes escutadas pelo eu lírico em seu quarto de hotel, em uma noite em Nova York:

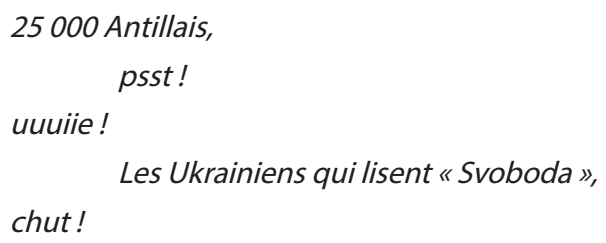




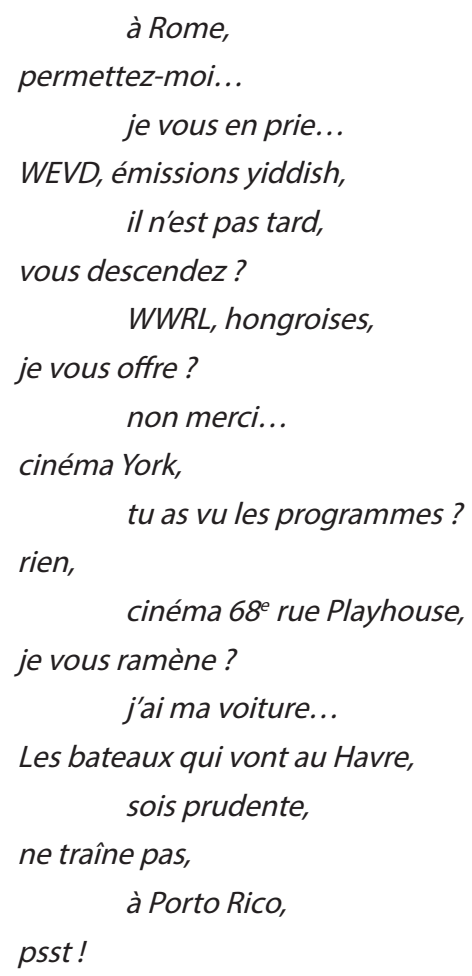

Em uma espécie de colagem, o escritor mescla vozes humanas às emissões radiofônicas e aos sibilos discretos que solicitam o silêncio ("psst !", “chut !", “psst !"), em vão. O poema inteiro se caracteriza por vozes que se cruzam e que se conectam de forma intercalada. O eu lírico está imerso em uma atmosfera sonora múltipla, de múltiplas vozes que, ao fim do poema, começam a se perder umas em meio às outras, restando apenas partes de palavras, restos de ecos, de repetições e de dizeres que não importam mais do que a própria voz que os transmite e que não se recuperam em meio à noite:

qu'est-ce que c'est ?
ce n'est rien,
rien,
uvez,
mal?
c'est là,

bonsoir, 


$\begin{array}{ll}\text { je t'aime, } & \text { entrez, } \\ \text { ormez, } & \text { ormir, } \\ \text { respirez, } & \text { respirez, } \\ \text { spirez, } & \text { pirez, } \\ \text { irez, } & \end{array}$

les bruits de la nuit.

De certa forma, a confluência de vozes tão distintas e que podem estar tão distantes espacialmente umas das outras, mas que se reúnem no poema por intermédio de um ouvinte atento e alheio às situações de suas emissões, encontra uma rima entre elas em meio a assonâncias (das vogais I, E, O) e a aliterações (das consoantes R, M, P). O que essas vozes emitem, o Dito que expressam, aqui não se faz relevante: importa mais o Dizer em si. A unicidade das vozes não está no significado que as suas palavras oralizam, pois não são palavras que remetem a um ser em particular; podem ser ditas por qualquer um, em diversos momentos. É a própria vocalização, o fato de se fazerem ouvidas por outros além dos destinatários a quem se dirigem que provoca os pedidos de silêncio, que podem ser dirigidos a uma voz em particular ou a todas elas juntas. Não há, no decorrer do poema, qualquer indício de que uma dessas vozes pertença ou não ao eu lírico, aquele que está à espreita e que as registra em seu "microfone", o que nos leva a algumas questões a esse respeito: é uma escuta ativa ou passiva?; há certa progressão entre essas múltiplas vozes que se encontram ou são todas simultâneas?

Aparentemente, percebe-se que houve uma seleção sonora, já que "les bruits de la nuit" não são só as vozes que se escutam, mas o próprio tráfego de veículos, os objetos que por ventura caem e se quebram ou que emitem ruídos estrondosos, o próprio abrir e fechar de portas, as campainhas e interfones... No entanto, nada disso aparece no poema, mas é interessante observar que as múltiplas vozes são denominadas "bruits". Quem as escuta e registra não considera os seus significados, mas suas vocalidades, como já dito anteriormente. São vozes da vida cotidiana, corriqueiras e diárias, sem vínculo com o pensamento, por isso são barulhos, são "l'expression de la foule ou de la majorité" (ButoR, 2017, [s.p.]) e não de um pensamento que depende da voz para ser completo, como no caso do título da obra Pensées à voix haute, em que Butor depende de sua voz para a construção de seu livro vocálico.

Mesmo que definida como barulho no caso desse poema, a voz, para o escritor, não é comunicação, mas sim a própria função da literatura. São as 
múltiplas vozes que dão vida a essa noite do eu lírico e é graças a estas que o poema se faz. Nas palavras de Cavarero,

Talvez valha a pena assinalar que, na linguagem da crítica literária, "voz" é hoje um termo técnico que indica a peculiaridade do estilo de um poeta ou, mais genericamente, de um autor. Esse uso é interessante principalmente por remeter a uma unicidade vocálica que permanece subentendida e que, ao mesmo tempo, é alterada e deslocada de seu registro sonoro: "O fato de que não existem duas vozes humanas absolutamente idênticas faz com que, na literatura, a 'voz'se torne equivalente geral de diferença expressiva, perdendo qualquer referência à oralidade". Nesse contexto lexical, a "voz"de um autor, mesmo implicando o dado da unicidade de cada voz, corresponde então a um idioleto estilístico, ao ar de uma canção audível apenas mentalmente, ou seja, aquele ar que, não por acaso, Proust percebe através da leitura. Registrada, mas não tematizada, a unicidade de cada voz se torna, em outros termos, o pressuposto para a autenticidade da "voz"autoral referida no texto escrito. O jogo é sutil: o funcionamento da metáfora requer que a voz, em sua perceptibilidade sonora, seja única, mas a própria metáfora transforma o fato da unicidade na peculiaridade de um estilo consagrado à escrita. Se, em meio aos vários aspectos desse estilo, existe também um ar musical, exatamente aqui está a passagem preciosa que reaproxima a "Voz"da voz. (CAVARERo, 2011, p. 113-114)

O ar musical butoriano, principalmente em suas obras literárias para crianças, alcança sua plenitude nessa literatura que tem por essência a vocalização. Indo além do sentido de "voz" da teoria literária que remete à particularidade de seu estilo enquanto poeta e escritor, há o reencontro entre essa "voz" estilística e a voz enquanto registro sonoro. No poema "Manhattan invention", as múltiplas vozes estão encarceradas na leitura silenciosa do adulto. Somos capazes de identificar a polifonia presente no texto poético, mas não a encenamos enquanto leitores. Essa busca pela leitura oral, pelo texto sonoro, é o modus operandi da obra Pensées à voix haute, mas que ganha sua plenitude na literatura infantil, espaço esse destinado à leitura em voz alta, bem como à apreensão do texto pela relação entre palavra e imagem que ganha pleno sentido na leitura vocalizada. Em Pensées à voix haute, a leitura é a própria escuta, não há separação. As transcrições realizadas dessa obra e analisadas anteriormente estão repletas de marcas de oralidade de palavras que foram pensadas para serem ditas e não escritas. 
Já na literatura infantil, como será mostrado a seguir, texto e imagem fluem num único sentido: a voz. A musicalidade presente em cada palavra passa pela manifestação do traço da ilustração e culmina numa leitura em voz alta, sendo esta a própria essência da literatura para crianças. Há ainda, como será mostrado, uma outra voz que preenche o texto e que tem sua revelação ao final da obra, na conclusão da história. Essa voz é mais do que uma narrativa paralela: é o próprio logos da obra que ganha vida na vocalização, suscitando assim múltiplos pathé nos leitores, crianças e adultos.

\section{LEITURA}

Em "Représentations collectives", Butor apresenta uma breve evolução do processo de leitura e de conservação dos textos no Ocidente, passando da preservação dos textos pela repetição oral, depois por intermédio da escritura para, atualmente, ser possível produzir livros sonoros, como Pensées à voix haute, ao que Zumthor considera como um "retorno forçado da voz" no caso das media e, mais precisamente, como uma "ressurgência das energias vocais da humanidade, energias que foram reprimidas durante séculos no discurso social das sociedades ocidentais pelo curso hegemônico da escrita" (ZUMTHOR, 2018, p. 16):

Alors donc, il avait la conservation du texte par la répétition orale, puis ensuite il a eu la conservation du texte par l'intermédiaire de l'écriture. Aujourd'hui nous pouvons conserver le texte autrement, nous avons des enregistreurs... J'ai ici un petit micro très ingénieux, et puis on enregistre ça sur des cassettes ou sur des CDs. On fait toute sorte de support aujourd'hui qui ont la particularité qu'ils ne passent pas par l'intermédiaire de notre écriture habituelle. On peut dire qui s'agit d'un type d'écriture, mais c'est un type d'écriture tout à fait différent de l'écriture alphabétique dans laquelle nous avons était élevés, donc il y a une profonde transformation. Encore aujourd'hui, le travail sur le langage se fait en grande partie par l'intermédiaire du livre et ce travail sur le langage est quelque chose d'absolument essentiel. Si nous inventons une nouvelle façon de parler des choses, nous transformons les choses. (BuToR, 2017, [s.p.])

É por meio do livro, do seu trabalho sobre a linguagem e da invenção de novas formas de se falar das coisas, que passa também pela tradução como mostrado anteriormente, que as coisas do mundo são transformadas. O livro já não mais necessita da escrita alfabética para ser concebido. A escrita habitual já não é mais sua única forma de existência nem de conservação do texto, o que transforma também os modos de leitura, visto que o conteúdo do livro sonoro "[...] é percebido pelo 
ouvido [...], mas não pode ser lido propriamente, isto é, decifrado visualmente como um conjunto de signos codificados da linguagem" (ZUMTHOR, 2018, p. 16).

Para Zumthor, "a diferença entre os dois aspectos da mediação (a voz se faz ouvir, mas se tornou abstrata) é, sem dúvida, insuperável" (idem, p. 16). O livro sonoro é capaz de transmitir a voz de Butor, por exemplo, mas, em três pontos levantados pelo medievalista, a voz registrada por meios eletrônicos aproxima-se da escrita: (i.) pela exclusão da presença de quem traz a voz; (ii.) pela anulação do presente cronológico, visto que a voz gravada é reiterável infinitamente e sem qualquer variação; e (iii.) pela artificialidade do espaço composto gerado pelo apagamento das referências espaciais da voz viva. "De todo modo, aquilo que se perde com os media, e assim necessariamente permanecerá, é a corporeidade, o peso, o calor, o volume real do corpo, do qual a voz é apenas uma expansão" (idem, p. 17), mas, em contrapartida, ganha-se o registro de uma voz que não tem mais corpo e que resiste, assim como a literatura (salvo questões de armazenamento e preservação inadequados), ao tempo, tornando possível ao menos conhecer e ter contato com uma voz que "vive" para além do corpo, como no caso de Butor, falecido em 2016. O objetivo de profunda transformação da linguagem, pretendido por Butor, é de fato alcançado, pois, ainda que tenha semelhanças com a escrita, é um outro tipo de escritura, "un type d'écriture tout à fait différent de l'écriture alphabétique dans laquelle nous avons était élevés" (Butor, 2017, [s.p.]).

A ausência dessa corporeidade não significa que não haja nos media alguma presença. Ela existe, em uma espécie de escala de intensidade, indo do mais intenso, o oral, ao menos intenso, a escritura, encontrando-se entre um e outro os híbridos, a exemplo do que chamo de livro sonoro. Na leitura, a presença corporal do escritor é sutil, "mas subsiste na presença invisível, que é a manifestação de um outro, muito forte para que minha adesão a essa voz, a mim assim dirigida por intermédio do escrito, comprometa o conjunto de minhas energias corporais" (ZUMTHOR, 2018, p. 63). Essa voz que fala por intermédio do texto escrito, muitas vezes, na literatura, traz em si múltiplas vozes ou desdobra-se ela mesma no que Butor chama de "voix temporelles", como no caso do diálogo do escritor consigo mesmo, comentando sobre fatos já relatados no mesmo espaço da página de seu "journal intime" (Butor, 2017, [s.p.]). A compreensão de uma obra pelo leitor, para Butor, passa pela identificação com todos os personagens, visto que é ele, enquanto leitor, quem dará a parole aos textos e aos personagens de uma obra:

Le lecteur et [le romancier] lui-même sont propres acteurs et il et lui-même ont toute une troupe. Quand je lis un roman [...] je m'identifie à certain personnage [...] mais pour pouvoir comprendre l'histoire, il faut que je m'identifie aussi aux autres 
personnages. Il faut que je les fasse parler. Lorsque je lis, [...] c'est moi-même qui vais donner la parole aux textes que je lis. Les personnages qui se trouvent dans les romans c'est moi qui vais les donner une parole qui n'est pas entendue, mais qui à l'intérieur de moi-même va quand même être un ensemble de dialogues. (idem)

Para Butor, o papel do leitor está diretamente ligado ao do ator, já que é ele próprio ator e possui toda uma trupe que o acompanha. Cabe a ele acolher todos os personagens, independentemente de ele se identificar ou não com estes para que a história seja compreendida. Nesse aspecto, o leitor age também como um deus, capaz de dar a parole não só ao texto como também a todos esses personagens. Essa parole ressoa em seu interior, compondo nesse espaço recluso e inacessível da mente o conjunto de diálogos, de vozes que se cruzam e entrecruzam durante a leitura.

"Quand j'étais enfant", afirma Butor, "j'ai appris par cœur un certain nombre de textes et c'était quelque chose de très utile parce que ça faisait entrer dans les textes d'une façon tout à fait différente, comme des acteurs apprennent par cœur leurs rôles" (idem). A leitura oral seguida da memorização dos textos lidos, que, para tanto, precisam ser relidos diversas vezes até entrarem no "coração" ("par cœur"), proporcionou uma experiência única para o escritor, de mergulho dentro dos textos e de uma percepção completamente diferente e particular dessas tessituras. Essa nova forma de entrar nos textos literários e de armazená-los na memória possibilita uma contínua oralização desses textos, que ressurgem ao bel-prazer de seu emissor-leitor. O texto ganha, então, vida pela vocalização de seu registro na memória, ao que o escritor associa a natureza da aprendizagem dos atores de seus papéis. Leitor e ator são performers da literatura oralizada.

A transmissão poética pela voz, para Zumthor, faz com que o lugar da obra seja desvinculado do texto e passe a contemplar os elementos performanciais, não mais textuais, mas sim de relação corpórea, para uma recepção sensorial. "O termo e a ideia de performance tendem [...] a cobrir toda uma espécie de teatralidade: aí está um sinal. Toda 'literatura' não é fundamentalmente teatro?" $(2018$, p. 19). As regras da performance controlam simultaneamente tempo, lugar, finalidade de transmissão, ação do locutor e resposta do público. Para a comunicação, sua importância pode ser ainda mais relevante que as próprias regras textuais contidas na obra. A aprendizagem das obras "par cœur" coloca em cena o corpo do leitor/ator, transformando o momento da declamação em pura teatralidade, portanto performance, sendo sua recepção sensorial. No caso de saber de cor uma obra, ela já não mais é lida em seu sentido puramente textual; o corpo sente os efeitos de cada palavra, o peso e as emoções que elas transmitem; a própria voz que declama carrega em si todos os elementos 
capazes de despertar a resposta do público.

Se pensarmos no caso do poema Zoo e das ilustrações que o acompanham, obra esta encomendada por uma revista pedagógica para compor material didático da primeira infância que, na França, corresponde à fase de letramento e implica acompanhamento de um professor e leitura em voz alta, característica própria da literatura infantil, percebemos que todo esse contexto performático faz parte da leitura da obra e representa sua própria essência, sua finalidade primordial de existência enquanto literatura, de modo a engendrar o contexto real e a determinar finalmente o alcance da obra (ZUMTHOR, 2018, p. 30):
À la tombée de la nuit
Quand se sont refermées les griles
L'éléphant rêve à son grand troupeau
Le rhinocéros à ses troncs d'arbres
L'hippopotame à des lacs clairs
La girafe à des frondaisons de fougères
Le dromadaire à des oasis tintant
Le bison à un océan d'herbes
Le lion à des craquements dans les feuilles
Le tigre de Sibérie à des traces dans la neige
L'ours polaire à des cascades poissonneuses
La panthère à des pelages passant dans les rayons de lune
Le gorille à des bananiers croulant de leurs feuilles violettes
L'aigle à des coups de vent dans des canyons de nuages
Le phoque aux archipels mouvants de la banquise disloquée
Les enfants des gardiens à la plage

No texto de Zoo, os animais e as crianças não falam, apenas sonham. Eles sonham com seu habitat natural, longe das limitações do espaço do zoológico urbano gerido pelos adultos. É como se todo aquele ambiente artificial tirasse deles suas vozes, mas que eles ainda fossem capazes de sonhar e de, nos sonhos, deslocarem-se para a realidade que Ihes define enquanto seres. Sendo a performance "o único modo vivo de comunicação poética" (ZUMTHOR, 2018, p. 33), quais são os pressupostos metodológicos para realizar uma leitura como a do poema Zoo? Ao considerar que ele foi pensado para ser usado em ambiente de ensino e dependente de uma figura adulta que conduzisse os corpos infantis para dentro e para além do texto, parece haver uma voz que a orienta e que a ensina a ler, pois "a leitura se aprende, nos entretemos com ela; ela exige esforço e constância; na linguagem corrente, a palavra cultura designa o hábito, seus efeitos" (idem, p. 62) que precisam ser ensinados por alguém que seja leitor proficiente, capaz de ler em voz silenciosa mas também em voz alta. 
E como se ensina a ler? Lendo. Mas a leitura silenciosa corresponde à etapa final da leitura, sendo seu início puramente oral, vocalizado. É preciso, portanto, ler em voz alta para se ensinar a ler, e não uma leitura qualquer, monótona, sem ritmo, mas uma leitura capaz de transmitir toda "a materialidade, o peso das palavras, sua estrutura acústica e as reações que elas provocam em nossos centros nervosos", pois todo texto poético é por natureza performativo (idem, p. 50-51). “Em uma situação de oralidade pura”, e aqui incluo a leitura oral, Zumthor salienta que

todas as funções desta (ouvido, vista, tato...), a intelecção, a emoção se acham misturadas simultaneamente em jogo, de maneira dramática, que vem da presença comum do emissor da voz e do receptor auditivo, no seio de um complexo sociológico e circunstancial único. (idem, p. 62)

Além do ouvido que capta o som da voz que lê, os olhos acompanham tanto o emissor quanto as palavras e as imagens do texto, que se materializam e ganham peso e forma diante do receptor, agindo sobre o intelecto e as emoções. A voz que narra dá vida à voz do texto: no caso do poema Zoo, ela dá voz àqueles que se silenciaram diante do mundo, mas que não deixam de sentir e de transmitir seus sonhos.

O complexo sociológico e circunstancial da sala de aula é composto de professor, alunos, literatura para a infância, desenhos, alfabeto, números, brincadeiras, jogos e música - na situação ideal de ensino -, por isso a importância da literatura infantil ilustrada: palavras e imagens ganham vida diante da voz do emissor e é desse modo que o leitor apura seus ouvidos, seus olhos e sua percepção para uma outra voz que compõe o texto de forma sutil e não vocalizada:

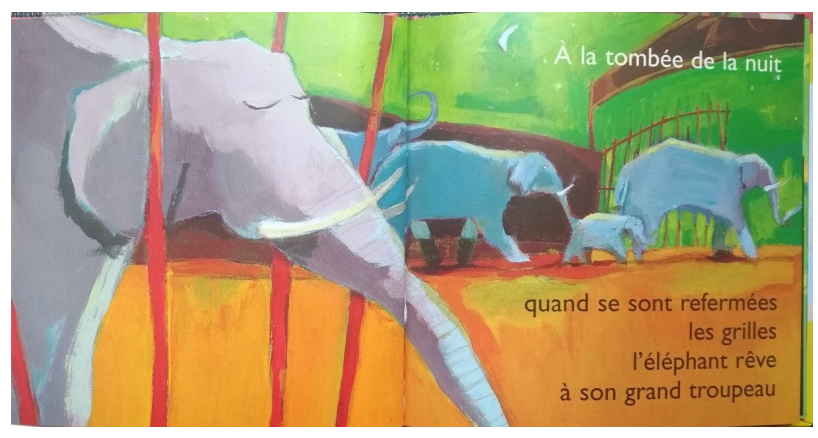

Figura 1 - Primeira página dupla: os elefantes 
Pelas ilustrações, percebemos que o texto adquire uma nova percepção além daquela transmitida pela oralização: a outra voz que compõe o texto deve-se em grande parte às imagens, mas muito de sua essência parte da relação triangular emissor-obra-ouvinte/leitor. Na sequência anterior, composta dos três primeiros versos do poema, vemos que na primeira dupla página o sonho do elefante é apresentado na imagem como uma debandada do zoológico junto à sua manada. $O$ texto escrito não traz essa informação, é a voz da ilustração que a apresenta.

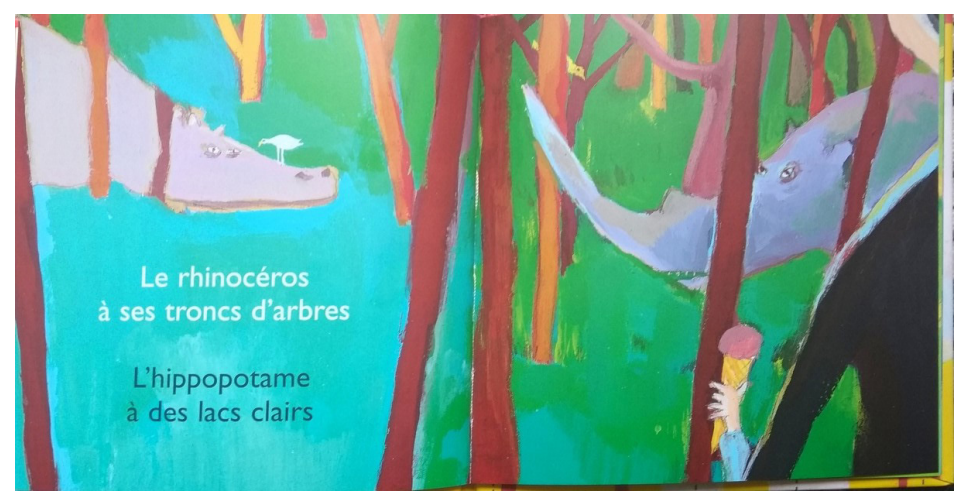

Figura 2 - Segunda página dupla: os rinocerontes Fonte: Zoo (BUTOR, 2001)

Já na segunda dupla página, os animais estão sonhando e sendo observados de dentro de seus sonhos por um adulto e por uma criança com um sorvete em uma das mãos. Somos nós que os vemos de dentro dos sonhos desses animais, por intermédio do texto, ou são os personagens ilustrados que os veem agindo de dentro dos seus sonhos? Seriam essas personagens os leitores da história, professor-aluno, pais-filho? Essas personagens veem o mesmo que nós, leitores, vemos ou há ainda imagens escondidas da história e que devemos imaginar?

Encaminhando a leitura da obra para a sua conclusão, deparamo-nos com um momento importante: o efeito gerado pelo livro ilustrado. Esse é um efeito que depende, intrinsecamente, da voz que o oraliza, da sua relação com o texto, com a imagem e com o receptor. $\mathrm{O}$ sentimento de contentamento ao final da leitura, no caso da literatura infantil, não depende só do texto, mas da sua atuação, da performance de um corpo que o ligue às imagens que o acompanham. Já foi falado anteriormente da importância do riso para Michel Butor, que declarou em Pensées à voix haute buscar naturalmente 
"la délicatesse dans le rire". Para o escritor, é importante nos questionarmos "qu'est-ce qu'il fait que telle image, que tel texte provoque en nous un sourire qui est toujours la marque d'un grand plaisir d'un type particulier ?" (idem, [s.p.]).

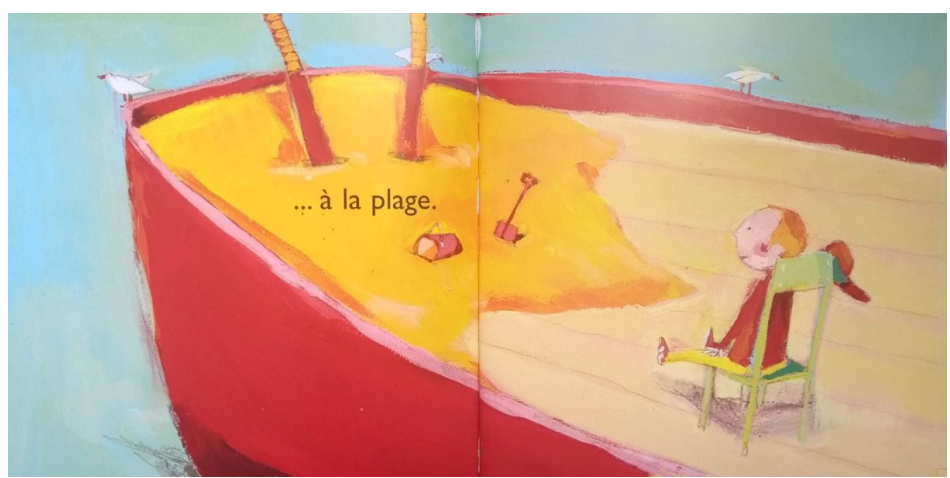

Figura 3 - Penúltima página dupla: o menino no zoológico, triste Fonte: Zoo (BuTOR, 2001)

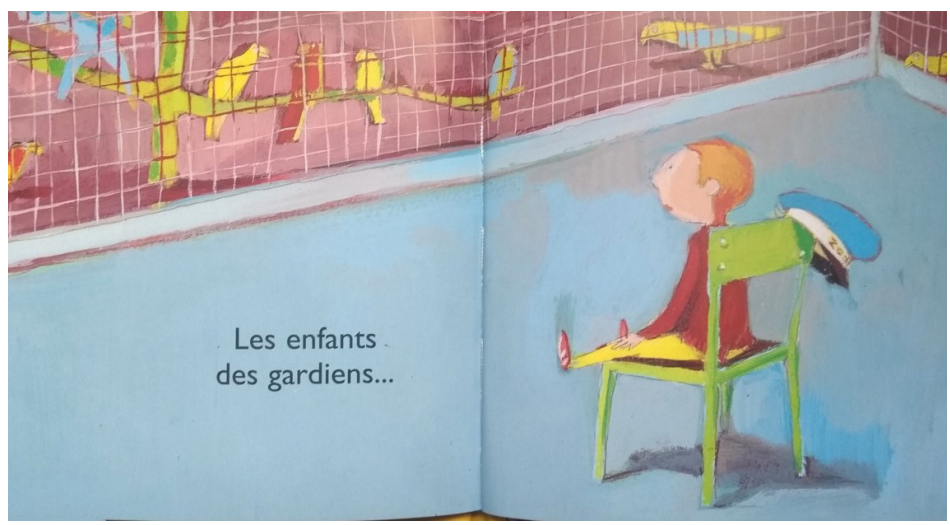

Figura 4 - Última página dupla: o menino na praia, feliz Fonte: Zoo (BUTOR, 2001)

O que faz com que tal imagem e tal texto provoquem em nós um sorriso representativo de um prazer particular? No caso de Zoo, ao menos para mim, esse sorriso vem da constatação de que as crianças retratadas, 
filhas do zelador do zoológico, apresentadas na imagem como um único menino ruivo na penúltima dupla página com o semblante um pouco abatido e significantemente sob o controle do boné de zelador do pai, ganha um sorriso ao ter seu sonho de estar na praia materializado: já não está mais sob o controle de um adulto, que de certa forma o obriga a estar diante de pássaros engaiolados, mas pode finalmente ser devidamente uma criança e carregar um boné de menino que ainda combina com sua camiseta; os pássaros agora estão livres e podem voar ou descansar na proa do navio. A praia é o habitat natural da criança, e é esse sonho de se reconhecer como pertencente a outro espaço que não aquele do zoológico que evidencia a relação visceral entre a criança (ou as crianças) e os animais aprisionados. As crianças não deixam de estar aprisionadas à realidade do adulto, mas é através de seus sonhos que elas reconhecem pertencer a outro ambiente, assim como os animais que elas encontram no zoológico.

Retomando as palavras de Zumthor, a noção de performance possui "um elemento irredutível, a ideia da presença de um corpo. Recorrer à noção de performance implica então a necessidade de reintroduzir a consideração do corpo no estudo da obra" (2018, p. 37). Mas de que forma podemos reintroduzir o corpo no estudo da literatura infantil? A meu ver, é compreendendo o complexo sociológico e circunstancial da sala de aula e da introdução à literatura durante o letramento. Se pensarmos que a criança é de personalidade aberta, ainda em construção, essa personalidade depende em grande parte de uma outra para se elaborar, uma outra que sirva de exemplo e de inspiração, tornando-se necessária a presença do adulto. Desse mesmo modo, a literatura infantil precisa do adulto atuando em sua performance e orientando tanto a escuta quanto a visão, o intelecto, o tato e as emoções da criança em sua experiência de leitor iniciante e em formação. Com persistência e dedicação, o hábito da leitura se instala, possibilitando um desenvolvimento saudável e a passagem para a leitura silenciosa, mas sem nunca perder o vínculo com a experiência de leitura em voz alta da infância que, para Butor, representa o retorno, por meio da literatura, à personalidade aberta da criança:

Ainsi, la littérature est par excellence le passage d'une personnalité fermée à une personnalité qui s'ouvre, et cette personnalité c'est toujours une personnalité qui à un moment ou un autre s'est fermée et donc qui peut trouver son ouverture lorsqu'elle remonte un peu à l'intérieur de son enfance. La littérature est ainsi une espèce de bain de jouvence dans lequel l'enfance continue à l'intérieur de l'âge adulte et dans laquelle la communication avec autrui est perpétuellement rétablie. (BuTOR, 2017, [s.p.]) 
Além disso, se retomarmos Dolar (2014), veremos que a relação entre voz e consciência está presente na leitura e age sobre esta. Ao identificarmos uma voz no texto, esta age nos fazendo buscar um referente de imagem que a complete ou que a corporifique em nossa mente, podendo ou não corresponder à imagem ilustrada. Mas, como relembra Calvino, "qualquer imagem que você tente atribuir a ela em sua fantasia, a imagem-voz será sempre mais rica" (1995, p. 39), sendo a voz uma imagem-voz, portanto, completa em si. A ilustração é, portanto, também uma voz sem deixar de ser imagem. O livro infantil, composto de texto, imagem, narrador e personagem, é exemplo de que a multiplicidade de vozes na literatura vai muito além da palavra escrita; ela a transcende.

AMAYI LUIZA SOARES KOYANO - Desenvolve trabalho de mestrado sobre Michel Butor no Programa de Estudos Linguísticos, Literários e Tradutológicos em Francês da USP. Ensaio apresentado à disciplina "Poéticas e políticas da voz", ministrada pelo professor Roberto Zular no segundo semestre de 2018. Contato: amayi@usp.br 


\section{REFERÊNCIAS BIBLIOGRÁFICAS}

Butor, Michel. Pensées à voix haute. Vincennes: Frémeaux, 2017.

Butor, Michel. "Manhattan invention". In: Anthologie nomade. Paris: Gallimard, 2004.

Butor, Michel. Zoo. Voisins-le-Bretonneux: Rue du Monde, 2001.

Butor, Michel. (1962) "Mobile”. In: Fuvres Complètes de Michel Butor - Le génie du lieu 1. v. 5. Paris: La Différence, 2008.

Calvino, Italo. "Um rei à escuta". In: Sob o sol-jaguar. Trad. de Nilson Moulin. São Paulo: Companhia das Letras, 1995.

Cavarero, Adriana. Vozes plurais: filosofia da expressão vocal. Trad. de Flavio Terrigno Barbeitas. Belo Horizonte: UFMG, 2011.

Cesarino, Pedro de Niemeyer. "A voz falível: ensaio sobre as formações ameríndias de mundos". Literatura e Sociedade, São Paulo, v. 19, n. 19, p. 76-99, 2014.

Dolar, Mladen. "Ética da voz". Trad. de Fábio Roberto Lucas. Literatura e Sociedade, São Paulo, v. 19, n. 18, p. 151-166, 2014.

Meschonnic, Henri. Linguagem, ritmo e vida. Trad. de Cristiano Florentino. Belo Horizonte: FALE/UFMG, 2006.

Morello, André-Alain. "Butor, œuvre des frontières et écriture-monde". In: ArBeX, Márcia; Allemand, Roger-Michel. (orgs.) Universo Butor. Belo Horizonte: C/ Arte, 2012.

Zumthor, Paul. Performance, recepção, leitura. Trad. de Jerusa Pires Ferreira e Suely Fenerich. São Paulo: Ubu, 2018. 